\title{
Moc v dialogickém vyučování ${ }^{1}$
}

\author{
Klára Šed’ová \\ Masarykova univerzita, Filozofická fakulta, Ústav pedagogických věd
}

Redakci zasláno 17. 6. 2014 / upravená verze obdržena 1.11. 2014 / k uveřejnění přijato 20.11. 2014

\begin{abstract}
Abstrakt: Cílem této studie je prozkoumat mocenské vztahy mezi učitelem a žáky v kontextu tzv. dialogického vyučování, to znamená takového typu výuky, v němž je stimulována aktivní účast žáků na výukové komunikaci. Článek na datech z výzkumu zaměřeného na zavádění dialogických postupů do vyučování humanitních předmětů na druhém stupni základní školy ukazuje, že v dialogickém vyučování dochází k cirkulaci moci mezi učitelem a žáky. To znamená, že nastavení vzájemných vztahů mezi učiteli a žáky umožňuje funkční přelévání moci mezi oběma stranami. $V$ př́spěvku jsou dále identifikovány dílčí elementy cirkulace moci, jimiž jsou snížení dominance učitele a dosažení shody na definici situace mezi učitelem a žáky.
\end{abstract}

Klíčová slova: moc, dialogické vyučování, výuková komunikace

Cílem této studie je prozkoumat mocenské vztahy mezi učitelem a žáky v kontextu tzv. dialogického vyučování, to znamená takového typu výuky, který je charakteristický vysokou mírou žákovské participace na komunikaci. Podle Lefsteina a Snellové (2014, s. 135) je koncept dialogického vyučování založen na přesvědčení, že žáci se učí nejlépe skrze aktivní zapojení do bohaté a stimulativní výukové komunikace. Nejde přitom jen o to, aby žáci hovořili častěji a déle, než je ve školní praxi běžné, ale aby byli iniciativní a autonomní. V takto pojatém vyučování žáci kladou otázky či spontánně komentují repliky jiných mluvčích - do určité míry tak mohou ovlivňovat témata, která budou nastolena, i směr, jímž se rozprava mezi učitelem a žáky bude ubírat. ${ }^{2}$ V tomto př́spěvku navazujeme na starší studii (Šed'ová, 2011), ve které jsme zkoumali mocenské vztahy na vzorku běžných vyučovacích hodin. Nyní chceme prostřednictvím analýzy vzorku dialogicky pojatých vyučovacích hodin prověřit hypotézu, zda specifické výukové postupy dialogického vyučování předpokládají také specifické uspořádání mocenských vztahů.

1 Tento text je výstupem z projektu GA ČR: GA13-23578S financovaného Grantovou agenturou České republiky. Autorka děkuje za poskytnutou podporu.

2 Blíže ke konceptu dialogického vyučování např. Šed'ová, Švaříček a Šalamounová (2012).

DOI: $10.5817 /$ PedOr2015-1-32 


\section{Moc jako klíčová dimenze vztahů mezi učiteli a žáky}

Vztahy mezi učiteli a žáky jsou jedním z evergreenů pedagogického výzkumu. Řada empirických studií (např. Baker, 2006; O’Connor \& McCartney, 2007; O'Connor et al., 2011; Pianta \& Stuhlman, 2004) dokládá, že dobré vztahy mezi učitelem a žáky pozitivně ovlivňují žákovské výsledky a snižují výskyt negativních forem žákovského chování. Při přemýšlení o vztazích mezi učitelem a žáky je přitom třeba mít na zřeteli fakt, že mají specifickou mocenskou strukturu (Winograd, 2002).

V pedagogických studiích bývá moc vymezována jako potenciál ovlivňovat jednání jiné osoby nebo skupiny lidí (McCroskey et al., 2006), přičemž může jít stejně tak o to, něčí chování změnit, jako je posílit a udržet ve stávající poloze. Neznamená to však, že by moc bylo možné operacionalizovat jako vlastnost nebo atribut jednotlivce. Jak uvádí Foucault (2000), moc je rozptýlená sociální síla, která podmiňuje a omezuje jednání všech zúčastněných aktérů a tvaruje jejich vztahy. Šalamounová, Bradová a Lojdová (2014, s. 380) upřesňují, že jde o kontextově vázané uspořádání, v jehož rámci učitel i žáci (jakožto jednotlivci i skupina) vzájemně ovlivňují své jednání. Tím se ve zkratce říká, že moc ve školní třídě není automaticky „vlastněna“ učitelem, nebot' také žáci dokážou účinně ovlivňovat jednání ostatních. Zároveň platí, že moc je ve školních třídách všudypřítomná, nikdy se z interakcí nevytrácí a nepřetržitě se přelévá mezi učitelem a žáky, nebot' obě skupiny sledují cíle, jichž chtějí dosáhnout (viz dále). ${ }^{3}$

Při tom všem však platí, že učitel ve školní třídě disponuje větší mírou moci než žáci a obvykle si udržuje dominanci v tom smyslu, že kontroluje a řídí dění ve třídě. To je dáno rozdílem ve zdrojích, z nichž oproti žákủm může čerpat. French a Raven (1959) a Raven (2008) identifikovali šest bází, z nichž může být moc odvozována: (1) informační (založena na vysvětlení, proč je dobré podřídit se pokynům), (2) odměňovací (založena na schopnosti udělit odměnu), (3) výkonná (založena na schopnosti udělit trest), (4) legitimní (vyplývající ze společenské pozice či role), (5) expertní (založená na expertním vědění) a (6) vztahová (založená na emocionální identifikaci, na potřebě zalíbit se oblíbenému člověku). Ve škole, jakožto hierarchicky strukturované instituci, nemají jednotlivci rovný přístup ke všem bázím. Je to výlučně učitel,

\footnotetext{
Na tomto místě je třeba připomenout, že vedle termínu moc existuje řada dalších, které lze použít pro označování týchž či příbuzných fenoménů, jako jsou kázeň, poslušnost, disciplína či autorita, autoritativnost. Dobrý přehled těchto termínů a způsobů, jimiž se uplatňují v české pedagogické produkci, podávají Šalamounová, Bradová a Lojdová (2014).
} 
kdo může odvozovat svoji moc z legitimní báze, a rovněž míra, v níž je vybaven expertním věděním, informacemi a možnostmi udělovat trest a odměnu, je v porovnání se žáky mnohem vyšší.

Ačkoli je tedy moc kontextově vázaná sociální síla, která formuje jednání učitele i žáků, v realitě školní třídy je to učitel, kdo má více zdrojů k tomu, aby ji centralizoval do svých rukou. Tato centralizace nikdy není úplná, přesto však existují uspořádání, kdy jsou učitelé silně dominantní a velmi striktně kontrolují aktivity žáků. Na druhé straně existují uspořádání se symetričtějším (decentralizovaným) rozložením moci mezi učitelem a žáky.

\section{Zkoumání moci ve školní třídě}

V pedagogických vědách existují různé linie zkoumání mocenských vztahů. $\mathrm{V}$ našem prostředí jsou poměrně dobře známy ${ }^{4}$ např́́klad práce týkající se tzv. interpersonálního stylu učitele (interpersonal teacher behaviour). Vlivné studie Wubbelse, Brekelmansové a jejich kolegů (Brekelmans, Levy, \& Rodriguez, 1993; Brekkelmans et al., 2011; Wubbels \& Brekelmans, 2005; Wubbels et al., 2006) postulují, že učitelé disponují určitým stabilizovaným stylem interpersonálního chování, v němž jsou klíčové dvě dimenze - vliv a blízkost. Vliv znamená míru dominance či submisivnosti, kterou učitel uplatňuje ve třídě, blízkost potom míru vřelosti či naopak odmítavosti, s níž učitel přistupuje ke svým žákům.

Ačkoli tato teorie popisuje primárně chování učitele, je v ní obsažen předpoklad, že určitý typ chování na straně učitele vyvolá odpovídající typ chování na straně žáka. V dimenzi blízkosti jde o reciprocitu - vřelost učitele vyvolá vřelost u žáků a nepřátelské chování učitele najde odezvu stejného typu u žáků. V dimenzi dominance dochází naopak k odezvě inverzní - žáci dominantního učitele se budou chovat submisivně a naopak, pokud učitel projeví submisivitu, žáci se ujmou dominantní role (de Jong et al., 2012).

Jiný příspěvek ke studiu moci ve třídě představují práce popisující, jaké strategie učitelé volí ke zvládání třídy (classroom management). Autoři z tohoto okruhu (např. Brophy, 2010; Tauber, 2007; Zuckerman, 2007) se snaží prozkoumat, jaké disciplinační postupy učitelů vedou k nastolení potřebné spolupráce mezi učitelem a žáky. Brophy (2010) shrnuje, že se v realizovaných výzkumech ukazuje spíše efektivita aktivit směřujících k optimálnímu

4 Viz Gavora, Mareš a Den Brok (2003), Mareš a Gavora (2004). 
uspořádání učebního prostředí nežli přímé zdůrazňování učitelské moci. Lewis a jeho kolegové (Lewis, 2001; Lewis et al., 2005; Roache \& Lewis, 2011) soustavně výzkumně dokládají, že existují typy učitelského chování (charakteristické svou agresivitou), které naopak výskyt nežádoucího žákovského chování zvyšují. Výzkumy zvládání třídy mají své praktické aplikace - vychází z nich příručky pro učitele ${ }^{5}$ obsahující sety pravidel pro udržení pořádku a kontroly ve tř́dě. ${ }^{6}$

Oba výše uvedené přístupy sdílejí předpoklad, že při správném postupu učitele dojde $\mathrm{k}$ tomu, že se žáci dobrovolně přizpůsobí jeho požadavkům, což je chápáno jako nutná podmínka efektivního vyučování a učení. Zcela jinou vědeckou tradici představují studie, které vycházejí z premisy, že žáci a učitelé představují svébytné skupiny, které sledují své partikulární cíle. Manke (1997) v této souvislosti užívá termíny učitelská a žákovská agenda. Učitelská agenda spočívá v kontrolování studentů v zájmu maximalizace jejich učení. ${ }^{7}$ Žákovská agenda je podle této autorky (Manke, 1997) s učitelskou v konfliktu: žáci dokáží nabourávat agendu učitele např́klad záměrnými chybami, ignorováním pokynů učitele, vykazováním lhostejnosti vůči učitelovým očekáváním či zaujímáním nepatřičných rolí). ${ }^{8}$ Podobně vidí situaci ve školní tř́ídě např́klad Winograd (2002, s. 345), podle něhož je základním cílem učitelů udržet třídu v ukázněnosti a přimět žáky k učení, zatímco pro žáky je centrální členství ve vrstevnické skupině a mentální stimulace. Může nastat situace, kdy se cíle obou skupin protnou, to znamená, že žáci jsou dostatečně mentálně stimulováni, mají př́ležitost k interakcím se spolužáky, výuka je baví a zároveň si disciplinovaně osvojují nové poznatky. Častěji však dochází k nesouladu, nebot' kurikulum není pro žáky vždy zajímavé a atraktivní, a proto se snaží školní práci vyhnout (Woods, 1983). Ve škole tak spolu koexistují dvě skupiny aktérů - učitelé a žáci - již situaci, v níž se ocitají, definují různým způsobem a hledají cesty, jak uspokojit své vlastní potřeby a naplnit své cíle.

V předcházející studii (Šed'ová, 2011) jsme nabídli alternativní konceptualizaci mocenských vztahů mezi učitelem a žáky, založenou na datech

V českém prostředí je známa kniha J. Cangelosiho Strategie řízení tř́dy (1994).

6 Mezi tato pravidla patří například udržování očního kontaktu se žáky, fyzické přiblížení se k nim, v př́padě, že učitel zpozoruje jejich nevhodné chování, poskytnutí signálu, že si učitel tohoto chování povšiml atd. (viz např. Emmer \& Evertson, 2009).

7 Konkrétní popisy jednání v rámci mocenské agendy učitelů lze najít v řadě empirických studií (viz např. Manke, 1997; Margutti, 2011; Lewis, 2001; Lewis et al., 2005).

8 Př́ípadové studie rebelií či vyostřených konfliktů mezi učitelem a žáky nabízejí např. Lapointe a Legault (2004) a McFarland (2001). 
z rozsáhlého výzkumného šetření etnografického charakteru (blíže viz Šed'ová, Švaříček, \& Šalamounová, 2012). Na základě analýzy videonahrávek výukové komunikace mezi učitelem a žáky jsme vytvořili typologii tzv. mocenských konstelací, které představují vzorec mocenských vztahů vznikající $\mathrm{v}$ interakci mezi učitelem a žáky.

Vzniklá typologie mocenských konstelací zahrnuje čtyři konstelace, při jejichž identifikaci byla klíčová dvě hlediska. Za prvé - do jaké míry je moc centralizována $v$ rukou učitele. Pokud je moc centralizovaná, učitel je silně dominantní a plně rozhoduje o tom, co se bude ve tř́dě dít. Naopak konstelace s decentralizovanou mocí se vyznačují cirkulací a sdílením moci mezi učitelem a žáky. Za druhé - do jaké míry obě strany sdílejí společnou definici situace, to znamená společný náhled na cíle a prostředky výuky. Jestliže je definice situace sdílená, znamená to, že se žákovská a učitelská agenda (viz výše) překrývají. Rozdílná definice situace znamená nesoulad mezi žákovskou a učitelskou agendou.

Kombinací výše uvedených hledisek vznikl model čtyř typů mocenských konstelací:

1. Zobání z ruky: konstelace, v níž je silně dominantní učitel, žáci s entuziasmem sdílejí jeho definici situace, vztahy mezi oběma skupinami jsou vřelé a osobní.

2. Přesilovka: konstelace, v níž je silně dominantní učitel, žáci nesdílejí jeho definici situace, avšak nestaví se mu otevřeně na odpor. Jsou spíše pasivně rezistentní, plní zadané úkoly, ale jen tak, aby se vyhnuli sankcím.

3. Cirkulace moci: konstelace, v níž je moc decentralizovaná, žáci jsou iniciativní a aktivně ovlivňují dění v hodině. Definice situace je sdílená oběma stranami, školní práce je žáky vnímána jako hodnotná a zajímavá.

4. Tahanice: konstelace, v níž je moc decentralizovaná, avšak žáci nesdílejí cíle učitele a obě skupiny bojují o to, kdo prosadí svoji definici situace. Vztahy mezi oběma skupinami jsou osobní, obsahují negativní emoce, vzájemná vyjádření nespokojenosti a nátlak na změnu chování.

Do výzkumu, v jehož rámci byl koncept mocenských konstelací vyvinut, bylo zahrnuto 16 učitelů a jejich tříd. Analýza ukázala, že nejběžnější mocenskou kostelací je přesilovka, která je zároveň pro učitele nejbezpečnější, nebot' prostřednictvím opakování navyklých a rutinních komunikačních schémat umožňuje udržet kázeň ve třídě i v př́ípadě, kdy žáci nemají k učiteli 
vytvořený pozitivní citový vztah a výkové činnosti pro ně nejsou zajímavé (viz Šed’ová, 2011).

\section{Na cestě $\mathbf{k}$ decentralizaci moci?}

Optimální nastavení mocenských vztahů mezi učitelem a žáky je v současnosti předmětem diskusí. Například Wubbels a další autoři studující interpersonální styl učitele považují za žádoucí vysokou míru dominance učitele v kombinaci s vysokou mírou vřelosti (viz např. de Jong et al., 2012; Wubbels \& Brekelmans, 2005).

Naproti tomu existuje v současné pedagogice zřetelný př́íklon $\mathrm{k}$ tomu, že by učitelská dominance měla být spíše oslabována. V zásadě jde o odklon od tradičního či behavioristického přístupu ke kázni a jeho nahrazení přístupem liberálně progresivistickým (Johnson et al., 1994) - v rámci tohoto přístupu je propagována decentralizace moci směrem od učitele k žákủm, přenesení zodpovědnosti za vlastní chování na žáky a demokratické vyjednávání pravidel vzájemné interakce mezi učitelem a žáky ve třídě.

Volání po utlumení učitelské dominance je způsobeno jednak celkovou demokratizací západní společnosti, jednak příklonem k novému pojetí vyučování a učení, jež má být orientováno na žáka (Garret, 2008). Pod širokou nálepku na žáka orientovaných přístupů spadá řada konkrétních koncepcí, například badatelsky orientované vyučování, stejně jako dialogické vyučování, jemuž se věnuji v této studii. Všechny tyto koncepce mají totožné teoretické pozadí a tím jsou sociokulturní teorie, reprezentované zejména Vygotským (1978) a Brunerem (1978). ${ }^{9}$

Brophy (2010) se domnívá, že základní principy udržení spolupráce a disciplíny, které byly definovány v průběhu dekád výzkumu zvládání třídy (viz výše), zůstávají nadále v platnosti a vyžadují jen určité modifikace či doplnění. Podle Brophyho (2010) nadále platí, že učitelé musí formulovat jasná a konzistentní očekávání a poskytovat př́mé instrukce a jasné klíče, podle nichž žáci rozpoznají, jaké chování se od nich očekává.

Naproti tomu jiní autoři tvrdí, že k efektivní realizaci výuky zaměřené na žáka je nutná změna mocenských vztahů se zavedením symetričtější interakce mezi učitelem a žáky (Chin, 2007; Mortimer \& Scott, 2003; Oliveira, 2010).

9 K uplatnění principů sociokulturních teorií v koncepci dialogického vyučování blíže viz Šedová et al. (2014). 
Empirických výzkumů v této oblasti není mnoho a nepřinášejí jednoznačné výsledky. Cornelius a Herrenkohl (2004), stejně jako Patchen a Smithenry (2014) ukázali, že moc souvisí se strukturou participace. Jestliže se při vyučování orientovaném na žáka změní struktura komunikace (žáci začnou klást otázky a vzájemně na sebe reagovat), změní se i mocenské vztahy ve tř́dě. Podobnou evidenci přinesli Reinsvold a Cochran (2012) ve vztahu k učitelským otázkám - jestliže učitel klade autentické otázky (tzn. otázky, na které není předem daná odpověd'), dochází $\mathrm{k}$ decentralizaci moci. Problémem těchto výzkumů je fakt, že jde o př́ípadové studie jednotlivých učitelů, kteří ovládli metodiku vyučování zaměřeného na žáka a adekvátně zacházejí s mocí ve třídě. Na druhé straně existují též studie (opět případové), které ukazují, jak obtížné je pro učitele bez použití tradičních disciplinačních postupů udržet ve třídě pozitivní pracovní klima, v němž je možné soustředěné vyučování a učení (viz např. Lefstein, 2002; Pace, 2003; Winograd, 2002). Uvedená rozpornost výsledků patrně naznačuje, že decentralizace moci je v kontextu vyučování zaměřeného na žáka možná a potenciálně prospěšná, avšak není jednoduché jí dosáhnout. Co chybí, jsou studie, které by nejenom dokládaly, že produktivní utlumení učitelské dominance je možné, ale též detailněji analyzovaly, jak toho úspěšní učitelé dosahují. Právě to je cílem výzkumu, o němž budeme referovat v následující části.

\section{Metodologie výzkumného šetření}

Jestliže jsme v předcházející studii (Šed'ová, 2011) zkoumali mocenské vztahy na vzorku běžných ${ }^{10}$ vyučovacích hodin v prostředí druhého stupně základní školy, $v$ tomto textu si klademe za cíl prozkoumat uspořádání mocenských vztahů v hodinách učitelů, jejichž způsob výuky se blíží dialogickému vyučování.

Data, s nimiž pracujeme, byla získána v rámci projektu Učitel a žáci $v$ dialogickém vyučování. ${ }^{11}$ Jde o výzkumný projekt zaměřený na změnu komunikačních postupů učitelů směrem $\mathrm{k}$ implementaci principů dialogického vyučování. Participující učitelé se účastní rozsáhlého programu profesního

10 Termínem běžné vyučovací hodiny zde máme na mysli skutečnost, že šlo o nevýběrový vzorek, do nějž byli na jednotlivých školách zařazeni všichni vyučující v určitém předmětu a ročníku. Ve všech případech šlo o klasickou frontální výuku s komunikací založenou na IRF struktuře (viz Šed'ová, Švaříček, \& Šalamounová, 2012).

11 Jde o projekt GA ČR: GA13-23578S, na kterém pracuje tým ve složení: Roman Švaříček, Klára Šed'ová, Martin Sedláček a Zuzana Šalamounová. 
rozvoje, v jehož průběhu i po jehož ukončení je monitorováno, zda a v jaké míře se proměňuje komunikace mezi učitelem a žáky. Podrobný popis metodologie celého projektu lze nalézt v jiném textu (Šed’ová et al., 2014), stejně jako první analýzy, jež svědčí o tom, že výuku učitelů, kteří prošli první vlnou realizovaného akčního výzkumu, lze považovat za dialogickou v tom smyslu, že dochází $\mathrm{k}$ navození zvýšené aktivizace žáků. V porovnání s běžným vzorkem (viz Šed'ová, Švařriček, \& Šalamounová, 2012) dochází v hodinách sledovaných $\mathrm{v}$ tomto projektu $\mathrm{k}$ tomu, že žáci častěji sami iniciují komunikaci a zároveň formulují delší a rozpracovanější promluvy (k metodice srovnání a ke statistické významnosti rozdílů mezi vzorkem dialogických a běžných vyučovacích hodin viz Šed'ová et al., 2014). Datovým zdrojem, s nímž pracujeme v této studii, jsou videonahrávky vyučovacích hodin, které - v souladu s tím, co bylo uvedeno výše - chápeme jako reprezentaci dialogického vyučování.

Na tomto místě se nebudeme orientovat na strukturní charakteristiky komunikace mezi učiteli a žáky (jako jsou typy učitelských otázek, rozvitost žákovských odpovědí apod.), nýbrž se budeme koncentrovat na to, jak jsou v dialogicky pojaté výuce nastaveny mocenské vztahy. Výzkumná otázka, kterou si klademe, zní, zda mocenské konstelace v dialogicky pojatých hodinách mají podobu cirkulace moci a pokud ano, jakým způsobem dochází k ustavování a udržování této konstelace.

Vzorek tvoří čtyři učitelé, kteří se zúčastnili první vlny výzkumného projektu Učitel a žáci v dialogickém vyučování, jež proběhla ve školním roce 2013/2014. Základní charakteristiky participantů uvádíme v tabulce 1. Participanti byli sledováni bud' při výuce českého jazyka, nebo občanské výchovy. ${ }^{12}$ Ve všech případech šlo o aprobované učitele s různou délkou praxe. ${ }^{13}$

12 Důvodem omezení výzkumu na dva předměty byl předpoklad, že komunikace v různých předmětech může být ovlivněna obsahem vyučované látky. Volili jsme humanitní předměty, a to proto, abychom získaná data mohli porovnat $\mathrm{s}$ daty $\mathrm{z}$ předcházejícího výzkumného projektu (viz Šed'ová, Švaříček, \& Šalamounová, 2012), kde jsme rovněž pracovali s učiteli českého jazyka a občanské výchovy. Důsledkem tohoto omezení je skutečnost, že naše závěry nemůžeme považovat za přenositelné do kontextu jiných předmětů.

13 Délka praxe nebyla výběrovým kritériem, chtěli jsme se pouze vyhnout začínajícím učitelům, kteří ještě nemají stabilizovaný styl výuky. Lze předpokládat, že délka praxe může působit jako intervenující proměnná a že se v průběhu kariéry učitele může způsob nakládání s mocí měnit. Tyto úvahy jdou však za hranice našich dat. 
Tabulka 1

Participantit ${ }^{14}$

\begin{tabular}{lllcl}
\hline Učitel & Délka praxe & Vyučovaný předmět & Ročník & Sídlo školy \\
\hline Hana & 20 let & český jazyk & 7. & malé město \\
Jonáš & 6 let & český jazyk & 7. & velké město \\
Václav & 3 roky & občanská výchova & 9. & vesnice \\
Radek & 8 let & občanská výchova & 9. & velké město \\
\hline
\end{tabular}

V průběhu projektu jsme shromáždili rozsáhlý korpus dat zahrnující individuální i skupinové rozhovory s učiteli, videonahrávky výuky, audionahrávky reflektivních rozhovorů stimulovaných videonahrávkami výuky, testy pro žáky. $\mathrm{V}$ tomto příspěvku pracujeme pouze $\mathrm{s}$ daty $\mathrm{z}$ videonahrávek výuky. Celkem jsme $u$ každého učitele pořídili 9 videonahrávek (každá v trvání jedné vyučovací hodiny, tzn. 45 minut), aby bylo možné dokumentovat vývoj, kterým participanti $\mathrm{v}$ průběhu celého procesu prošli. Analýza, kterou zde prezentujeme, se koncentruje na poslední čtyři videonahrávky, nebot' v této části programu již bylo možné výuku, kterou učitelé vedli, spolehlivě označit jako dialogickou. Přihlížíme ovšem také k předcházejícím videonahrávkám, pokud chceme poukázat na změnu či vývoj ve způsobu zacházení s mocí u daného učitele.

Všechny videonahrávky byly přepsány do formy protokolu vyučovací hodiny. Záznamový protokol obsahoval anonymizované základní identifikační údaje o dané vyučovací hodině a přepis verbální komunikace v průběhu celé výuky. Protokoly vyučovacích hodin jsme dále zpracovávali za použití softwaru ATLAS.ti určeného pro analýzu kvalitativních dat.

Analytická metoda, kterou v této studii používáme, odpovídá mikroetnografické analýze diskurzu (Bloom \& Carter, 2014), v jejímž rámci je vyučování chápáno jako sociálnělingvistický proces. Analýza pak znamená detailní popis vzájemné komunikace mezi učitelem a žáky s cílem identifikovat klíčové vzorce a pravidelnosti, které se v jejím rámci objevují.

V první fázi došlo $\mathrm{k}$ výběru datových fragmentů s dominantní mocenskou složkou. To znamená, že byly vyselektovány ty úseky komunikace, v nichž primárně neběží o zprostředkování vzdělávacích obsahů, nýbrž o mocenské vyjednávání různého druhu. $\mathrm{V}$ další fázi jsme tyto úseky podrobili otevřenému

14 Všem participantům bylo zaručeno, že data, která jsme od nich získali, budou anonymizována. Jména, která zde uvádíme, jsou pseudonymy. 
kódování, jehož účelem bylo identifikovat základní jevy, které s vyjednáváním o moci souvisejí. $V$ této fázi induktivně vznikla řada kódů, jež jsme dale kategorizovali a vytvořili tak set pěti kategorií (vytváření prostoru pro žáky, odkázňování, disciplinace, výměnný obchod, synchronizace emocí) ${ }^{15}$ vhodný pro popis mocenských vzorců napříč všemi sledovanými př́ípady.

Vzniklé kategorie jsme poté napojili na model mocenských konstelací vytvořený v přecházející studii (Šed’ová, 2011). Tento model je rozložen kolem dvou základních os. První z nich je osa centralizace-decentralizace moci, druhou z nich je osa sdílení-nesdílení definice situace. Každou z kategorií bylo možné spojit s pohybem po kontinuu jedné ze dvou uvedených os. Zatímco vytváření prostoru pro žáky, odkázňování a disciplinace se vztahují k ose de/centralizace moci, kategorie výměnný obchod a synchronizace emocí se vztahují k ose ne/sdílení definice situace.

Ve výsledku takto vedená analýza vypovídá o tom, jak dochází $\mathrm{k}$ decentralizaci moci a zároveň $\mathrm{k}$ dosažení shody na definici situaci, které jsou pro cirkulaci moci typické. Své nálezy představujeme v následujících kapitolách 5 a 6 .

\section{$5 \quad$ Výuka jako cirkulace moci}

$V$ této části příspěvku představíme blíže jednotlivé učitele a zaměříme se přitom na otázku, zda způsob, jímž jsou organizovány vztahy se žáky v jejich hodinách, odpovídá konstelaci cirkulace moci. Tato konstelace (viz Šed’ová, 2011) je charakteristická tím, že učitel slevuje ze své dominance, moc je rozptýlena mezi ním a žáky, cirkuluje ve třídě. Učitel a žáci přitom sdílejí stejnou definici situace - škola je místem učení a práce. V chování žáků se objevují prvky autonomie a spontaneity. Žáci vykazují vysokou angažovanost, velmi ochotně odpovídají na otázky učitele a rovněž sami pokládají otázky k učivu. Právě právo dotazovat se učitele lze vnímat jako jeden z klíčových projevů skutečnosti, že moc cirkuluje, nebot' ten, kdo se dotazuje, má v dané chvíli mocenskou převahu. Chování učitele bývá $\mathrm{v}$ rámci této konstelace přátelské a podpůrné, zř́ídka dochází ke kritice žákovských replik. Učitelé často zaujímají kvazivrstevnickou pozici, vysílají k žákům signály, že jsou jako oni. V komunikaci je přítomen humor, který častěji než od učitele vychází od žáků. ${ }^{16} \mathrm{~V}$ hodinách těchto učitelů se objevují aktivizující výukové

15 Tyto kategorie používáme jako názvy jednotlivých oddílů ve výsledkové části - kapitoly 6.1 a 6.2 .

16 Skutečnost, že učitelé na žákovské žerty přistupují a vycházejí jim vstříc, rovněž poukazuje na relativně rovnostářské rozložení moci ve třídě. 
metody - skupinová práce, diskuse, hraní rolí, projekty a jejich prezentace před třídou. Za jejich implementací stojí úvaha učitele, že klasická frontální výuka by žáky mohla nudit a tím pádem svádět k nekázni a odpírání poslušnosti.

Pojd'me se nyní podívat na to, jak výše uvedeným charakteristikám odpovídá výuka jednotlivých učitelů ve vzorku. Na úvod je možné říci, že ve výuce všech participantů nastává cirkulace moci, ačkoli u většiny z nich dochází rovněž k přesahům do jiných konstelací.

\subsection{Hana}

Struktura hodin literatury vyučovaných učitelkou Hanou byla po celou dobu trvání projektu velmi podobná. Pro každou hodinu bylo vždy vybráno jedno literární dílo, na začátku hodiny proběhla konverzace mezi učitelkou a žáky o tématech obsažených $\mathrm{v}$ knize, následně společné čtení úryvků z knihy, sumarizace děje a intepretace významu. $V$ hodinách je zjevná velmi vysoká angažovanost žáků, jíž Hana dosahuje kladením otevřených otázek, které se týkají životních zkušeností dětí a zároveň tematicky souvisí s probíraným textem. Jestliže Hana položí takovýto typ otázky, následuje řada odpovědí od různých žáků, kteří se chtějí dostat ke slovu. V těchto okamžicích ovšem někdy dochází $\mathrm{k}$ tomu, že je hladina šumu neúnosně vysoká, nebot' někteří žáci nečekají, až jim učitelka dá prostor a vykřikují své odpovědi paralelně $\mathrm{s}$ dalšími promluvami. $\mathrm{V}$ takových okamžicích Hana sahá k disciplinaci, která je typická spíše pro konstelaci zobání z ruky (viz Šed'ová, 2011) - jde o krátké sekvence, kdy učitelka na žáky zvýší hlas, napomíná je nebo na ně křičí, aby vzápětí přešla zpět do př́ijemného tónu. Tyto disciplinační vsuvky jsou obvykle směřovány $\mathrm{k}$ jednotlivým konkrétním žákům.

Fakt, že jsou žáci pozitivně zaujati nastolenými tématy a předloženými literárními texty je zjevný nejen $v$ tom, že se velmi iniciativně zapojují do komunikace $s$ učitelkou, ale též v tom, že se na konci hodiny velmi často dotazují na možnost vypůjčit si knihu ze školní knihovny, aby si ji mohli celou přečíst. Jak je pro konstelaci cirkulace moci typické, žáci jsou s to ovlivnit směr komunikace v hodině. Neostýchají se klást učitelce otázky, a to ani v př́ípadě, že tyto otázky indikují jejich neznalost nebo neporozumění a Hana na tyto otázky vždy reaguje vstřícně. Některé sekvence nabývají charakteru diskuse, do níž různí žáci vnášejí různé - předem neočekávané - impulzy, které dále ovlivňují směřování a vyústění komunikace mezi učitelkou a žáky. A konečně je pro Hanu typické, že se při volbě literárních děl, která budou ve výuce 
probírána, často nechává inspirovat žákovskými návrhy. Mnohdy se tak vede řeč o knize, kterou někdo ze žáků již četl, učitelce doporučil a při samotném výkladu se stává jejím partnerem.

\subsection{Jonáš}

Jonáš je učitelem, u něhož došlo $v$ důsledku účasti v projektu k markantní změně. Lekce, které realizoval $v$ jeho první části, totiž měly tendenci přepadávat směrem k tahanici (viz Šed’ová, 2011). Jonáš na své žáky vždy kladl velké nároky - jednak jim pokládal enormně obtížné otázky, jednak volil čtenářsky velmi náročná literární díla (Dalimilova kronika, dílo Jana Husa). Žáci se v této fázi často projevovali rezistentně - nereagovali na otázky učitele, otevřeně se ohrazovali vůči zadaným úkolům a dávali najevo, že je výuka nudí. Na to Jonáš reagoval naléháním na žáky, aby se více zapojovali. Nešlo však o naléhání direktivní, učitel vždy formuloval své požadavky velmi zdvořile, spíše ve formě prosby (místy též výčitky) a projevoval zájem o žákovský pohled na výuku a zájem na tom, aby žáky výuka bavila.

Na nahrávkách sejmutých v závěru projektu je situace zcela jiná. Jonáš nadále pracuje s obtížnými texty ze starší české literatury, avšak volí takové úkoly pro žáky, které jsou spojeny s jejich reálnou životní zkušeností a umožňují jim projevit vlastní názor. V hodině věnované dílu Jana Amose Komenského tak dochází nejen k seznámení žáků s jeho literárním odkazem, ale též například ke kolaborativnímu vytváření pravidel, jimiž by se učitelé měli řídit ve své práci. Otázky v těchto pasážích klade učitel, ale též sami žáci. Př́ípadně žáci formulují určitou myšlenku a další žáci na ně spontánně reagují. Co je podstatné - žáci pro danou chvíli přejímají značný díl moci, nebot’ stanovují regulativy pro učitele. Zároveň Jonáš ustupuje do pozadí a nechává je do značné míry řídit celou diskusi, žáci sami vzájemně usměrňují své chování a dozírají na dodržování komunikačních pravidel. Je patrná vysoká míra velmi aktivní participace, rezistence a projevy nudy se zcela vytrácejí.

\subsection{Václav}

Václav se od počátku výzkumu k žákưm se choval až demonstrativně rovnostářsky. Jde o nejmladšího učitele ve vzorku, který vůči žákům zaujímá vrstevnickou pozici, dokonce si s nimi tyká. V komunikaci mezi ním a žáky je ve velké míře př́tomný humor, který je iniciován jak žáky, tak učitelem. Často jde o delší sekvence jakéhosi škádlení, které si obě strany vyměňují. Václav dává najevo velkou benevolenci ve vztahu k žákovským replikám 
a požadavkům ( $v$ každé hodině např́íklad několik žáků postupně žádá o povolení odejít na toaletu a učitel jim vždy vyhoví). Zároveň však není patrná téměř žádná žákovská rezistence, vše běží hladce, zadané úkoly se žáci vždy snaží co nejlépe splnit, na otázky učitele reagují velmi aktivně.

Stejně jako u Jonáše, došlo i u Václava $v$ průběhu projektu k proměně některých komunikačních postupů, což se odrazilo i v mocenských vztazích ve třídě. $\mathrm{Z}$ analýzy nahrávek pořízených v první části projektu vyplývá, že Václav klade žákům mimořádně velké množství otázek, a tím je udržuje v permanentní pohotovosti. S množstvím otázek souvisí fakt, že odpovědi žáků jsou velmi úsporné. $V$ úvodních hodinách se téměř nevyskytují situace, kdy žáci bez vyzvání, iniciativně vstoupí do dialogu s učitelem. Celkově tedy na začátku vidíme Václava jako učitele, pro nějž je charakteristická rychlost (rychlý sled otázek a odpovědí) a zaplňování komunikačního prostoru vlastními aktivitami. Hodiny snímané v závěrečné části projektu jsou v tomto ohledu odlišné - snižuje se počet Václavových otázek a prodlužuje se délka žákovských replik. Jako by nyní docházelo k symetrizaci nejen na demonstrativní úrovni (tykání, škádlení), ale též na úrovni komunikačních struktur. Václav začal záměrně žáky vyzývat, aby si vzájemně pokládali otázky vztahující se k probírané látce. Nově se objevují také momenty, kdy si žák iniciativně bere slovo a formuluje dotaz, který může být směřován bud' na učitele, nebo na spolužáky. Oba tyto jevy svědčí o tom, že žáci dostávají ve Václavových hodinách více autonomie. Vyvazují se ze stereotypní pozice těch, kdo pouze odpovídají na otázky učitele, a mají možnost ovlivňovat směřování dialogu.

\subsection{Radek}

Radek se podobá Václavovi v tom ohledu, že si se žáky hojně vyměňuje vtípky a dává najevo benevolenci vůči žákovským prohřeškům (i v jeho hodinách lze pozorovat časté odchody na toalety, napouštění vody do lahví, vypůjčování pomůcek a podobně). Shodné je i to, že se v Radkových hodinách téměř nevyskytuje nekázeň a neochota řídit se pokyny učitele. Na rozdíl od Václava se Radek méně koncentruje na kurikulum. V komunikaci se prosazuje osobní rovina - Radek komentuje vlastnosti žáků a jejich mimovýukové aktivity, např́́klad dění na školním plese. Kontinuálně udržuje kontakt s jednotlivými žáky, oslovuje je zdrobnělinami a přezdívkami, a to i v proudu vlastního výkladu ve chvíli, kdy je nezamýšlí vyvolat. Koncentrace na osobní rovinu je charakteristická spíše pro zobání z ruky (viz Šed’ová, 2011) nežli pro cirkulaci moci, jíž Radkova výuka jinak odpovídá. 
Co je naopak pro cirkulaci moci typické, je volba aktivizačních a motivačních výukových metod. Radek často používá audiovizuální techniku, pouští žákům ukázky z filmů či hudbu. Žáci na tyto audiovizuální vsuvky reagují velmi pozitivně, je zřejmé, že je považují za atraktivní, Radek tedy tímto způsobem předchází pocitům a projevům nudy na straně žáků. Na druhé straně se může zdát překvapivé, že tento učitel dává zřetelně najevo, že ho některá probíraná témata nebaví a nepovažuje je za důležitá. Jde o narušení tradiční učitelské role, za nímž se v zásadě skrývá vzkaz, že učitel je stejný jako žáci, nebot' ani on nemá o předepsané obsahy permanentní zájem (kvazivrstevnická pozice). Paradoxně tím dochází k odbourávání žákovské rezistence, nebot' pokud učitel sám označí látku za nezajímavou, není třeba, aby totéž dělali žáci. Jak jsem již uvedla, Radek je prototypem přátelského a chápavého učitele, odvrácenou stranou jeho přístupu je však určitá obsahová vyprázdněnost (jako by bylo podstatnější si hodinu užít než se něco nového naučit).

\section{Co drží cirkulaci v chodu?}

Výše jsme popsali situaci v hodinách jednotlivých učitelů. Ačkoli všichni operují v konstelaci cirkulace moci, ${ }^{17}$ jejich konkrétní vzorce chování jsou dost různorodé. Přesto lze v této různorodosti vysledovat jednotící linie. Aby totiž byli s to cirkulaci moci udržet, musí všichni vyřešit dva základní úkoly: (a) udržet moc ve třídě decentralizovanou, to znamená snížit svoji dominanci; (b) dosáhnout společné definice situace a zajistit konsenzus ve věci cílů a prostředků vyučování.

\subsection{Rozpouštění dominance}

V práci všech sledovaných učitelů lze identifikovat dvě základní techniky, jimiž směřují k decentralizaci moci. Jde jednak o poskytování prostoru pro žáky, jednak o utlumení kázeňských zásahů. Co je zajímavé - v obou př́ípadech jsou učitelé připraveni použít jakousi „záchrannou brzdu“ za účelem opětovného nastolení vlastní dominance ve chvíli, kdy se práce ve tř́dě neodvíjí podle jejich představ.

\section{Prostor pro žáky}

Učitel, který poskytuje prostor pro žáky, jim dává možnost prezentovat jejich myšlenky, zkušenosti a názory a rovněž se podílet na rozhodování. To se děje

17 S jistými přesahy k jiným konstelacím. 
například tak, že pokud žáci nějakým způsobem komentují probíranou látku, učitel jejich komentář zachytí a rozvine jej jako stimul pro další konverzaci.

\section{Ukázka 1:}

$V$ hodině literatury čte učitelka Hana se žáky úryvek z knihy Robinson Crusoe. Po přečtení úryvku žádá žáky, aby shrnuli děj.

Ž Dana: Robinson vlastně se nechal jako ukecat, aby se potom plavil dál po moři.

U: (neverbální souhlas)

Ž Petr: Tak ten měl to moře asi hodně rád.

U: Myslíte, že měl rád moře?

ŽŽ: (Eva a Renata se překřikuji)

Ž Dana: $\mathrm{Ne}$, to ne, spíš měl rád plavbu. Nebo spíš, jak to vyprávěli ti námořníci a ten kapitán, tak to dobrodružství. Tak se nechal zlákat, no.

$\mathrm{U}$ : Plavil se někdo $\mathrm{z}$ vás po moři?

ŽŽ: Jo. (nahlas odpovídají bez přihlášení)

$\mathrm{U}:$ A bylo vám to př́ijemné?

ŽŽ: Jo. (mluví mezi sebou, bez přihlášení odpovídaji)

Ž Zdenka: Jako když nejsou moc velký vlny.

U: Každý si to musí samozřejmě vyzkoušet, že. Ale někdy možná ty větší vlny úplně př́ijemné by nebyly.

Ž Zdenka: Když to naráží do lodi, tak ne.

V ukázce 1 Hana nejprve žáky žádá, aby shrnuli děj. Již v tomto pokynu je obsažena určitá volnost, nebot' žáci mohou vyzdvihnout jako důležité různé aspekty děje. Následně žák Petr bez vyzvání vstupuje do komunikace (moc se přelévá k němu) a podotýká, že Robinson měl patrně rád moře. Zatímco v jiných mocenských konstelacích by učitelka jeho poznámku přešla, odbyla vtipem, př́ípadně jej pokárala za vykřikování, v ukázce 1 vidíme, že Hana na repliku navazuje a obrací ji do třídy. To znamená, že se žáku Petrovi podařilo určit obsah další konverzace. Zároveň ovšem dochází k naplnění cílů učitelky, nebot' v navazující replice žákyně Dana upřesňuje Robinsonovu motivaci pro plavbu na moři. Následně učitelka klade do třídy další otázku („Plavil se někdo z vás po moři?“), která už nevychází ze samotného literárního textu, nýbrž umožňuje žákům aktivovat jejich mimovýukovou zkušenost a propojit ji s tématem knihy. Indikátorem toho, že prostor pro žáky je otevřený, je jejich kvantitativní podíl na komunikaci (počet a délka jejich replik je nadstandardní), ${ }^{18}$ stejně jako skutečnost, že směr konverzace není předem dán a žáci jej svými replikami spoluurčují.

18 Viz Šed'ová, Švaříček a Šalamounová (2012). 
Otevření prostoru pro žáky může být iniciováno samotnými žáky (například na začátku další hodiny učitelky Hany se hlásí jeden ze žáků s tím, že s sebou do třídy přinesl knihu Švýcarský Robinson, která je variací na původní Defoeův text, a chtěl by o něm něco říci spolužákům), stejně jako samotným učitelem. Takovou situaci vidíme např́klad v ukázce $2 \mathrm{z}$ hodiny učitele Jonáše, který žádá žáky, aby vyjádřili svůj názor na jednání hlavního hrdiny v knize Důmyslný rytír don Quijote de la Mancha. V obou př́padech (iniciativa žáků, iniciativa učitele) však platí, že je vybrána a zviditelněna určitá promluva žáků (nikoli učitele), která tvoří výchozí bod nově otevřeného prostoru. ${ }^{19}$

\section{Ukázka 2:}

Vhodině literatury čte učitel Jonášse žáky úryvek z knihy Důmyslný rytír don Quijote de la Mancha. Následně klade žákům otázku, zda je rytírovo jednání (útok na větrné mlýny) smysluplné, nebo nesmyslné. Celá tř́lda považuje jednání za nesmyslné, učitel se staví do opozice. Po chvíli se přihlásí žák Adam s tím, že změnil názor.

Ž Adam: Protože si myslím, že každá činnost nebo každé chování člověka má nějaký smysl.

U: Rozuměli jste prosím vás tomu, co ted'ka právě ted' řekl Adam?

Ž Filip: Já už to taky chápu.

U: Adame, zkus to dát jako argument, ještě jednou. My si to ted', my si to ted' zkusíme obhajovat. Proč ty si myslíš, že Don Quijote a jeho chování je smysluplné?

Ž Adam: (dívá se na učitele) No, protože, jak už jste ř́íkal, že asi protože pro někoho má ta činnost smysluplnost a pro ty ostatní asi ne. Tak bych to asi myslel.

U: Řekni, řekni to jim. (ukáže na sedící žáky)

V ukázce 2 můžeme sledovat krystalický příklad cirkulace moci. Učitel má jasno v tom, jak charakter hlavního hrdiny a smysl jeho počínání interpretovat. Nechce však předávat hotovou poučku, nýbrž žáky přesvědčit - už v tomto bodě rezignuje na část své učitelské moci, nebot' ponechává žákům právo odporovat a vytvořit si vlastní protichůdný názor. $\mathrm{V}$ momentě, kdy se do diskuse přihlásí žák Adam, učitel ustupuje do pozadí a přenechává slovo Adamovi, který se pro tuto chvíli stává držitelem mocenské převahy, nebot' je mu udělena možnost vést výklad pro ostatní žáky („řekni to jim“).

Součástí prostoru pro žáky je rovněž poskytnutí autonomie v rozhodování. Sledovaní učitelé mnohdy vytvářejí příležitosti, aby se žáci sami mohli rozhodovat, at' už s ohledem na to, co je pro ně výhodné (kdy budou prezentovat

19 V ukázce 1 to byla věta žáka Petra: „Tak ten měl to moře asi hodně rád.“ V ukázce 2 je to Adamovo tvrzení: „Protože si myslím, že každá činnost nebo každé chování člověka má nějaký smysl.“ 
referát či psát písemku), nebo s ohledem na to, co považují za důležité nebo správné. Kupř́kladu učitelka Hana vyhledává společně se žáky na internetu informace o spisovatelce Ivě Procházkové a následně jim dává instrukci, aby si z toho, co bylo řečeno, každý vybral tři body a zaznamenal si je do sešitu. Podobnou situaci demonstruje ukázka 3 z hodiny učitele Václava, v níž žáci diskutují o etických aspektech eutanazie.

\section{Ukázka 3:}

$V$ hodině občanské výchovy učitel Václav se žáky dlouhou dobu diskutuje, zda eutanazie je či není přijatelná. Tř́́da nedospěje k jednotnému stanovisku.

U: Dobrý, dobrý, dobrý, já to uzavřu. Napište si tam každej svoji odpověd' na tu otázku. Jestli to je vražda, nebo není.

ŽŽ: (píš́ si do sešitů)

U: No ... napište si každý svoji, já nebudu psát (ukazuje rukou na tabuli).

Ž Karel: I s odůvodněním?

U: Jo, napište si i důvod, proč si myslíte, že to je či není.

Ž Alice: Co když nevím?

U: Tak si napiš ano i ne. Nebo napiš, nevím proto a proto. Jo? Klidně napište, i když si nejste jistí. Je to Váš pohled na věc.

Učitelé Hana i Václav požadují po žácích, aby rozhodli, co zapíšou do sešitů. Zápis je tradičně vnímán jako souhrn učiva, které je třeba si závazně osvojit. Jestliže žáci sami volí, co do sešitu zapíší, přejímají zodpovědnost za výběr a relevantnost vzdělávacích obsahů. Dostávají tedy do rukou moc do jisté míry definovat kurikulum. Naopak učitel se vzdává moci vyžadovat od žáků při zkoušení předem definované odpovědi - jestliže dopustil divergenci v zápisu, nutně musí tolerovat rovněž divergenci ve výsledcích učení.

\section{Odkázňování}

Ve školním prostředí zaužívaný terminus technicus ukázňování žáků znamená usměrňování žákovského chování směrem k normativně danému standardu. Termín odkázňování používáme jako antonymum, máme na mysli situace, kdy učitelé kázeňsky nezasahují.

Lze to ilustrovat na četných incidentech - např́iklad když učitel Radek zadává žákům písemku, jedna ze žákyň se ho ptá, zda může psát fialovou propiskou. Na to Radek odpovídá: „Ale jo, jakmile je konec roku, tak jo.“ V řadě případů učitelé při odkázňování nereagují na akce žákủ, nýbrž jsou sami proaktivní. Učitel Václav kupříkladu na začátku hodiny vchází do třídy, někteří žáci ho 
zdraví povstáním a někteří sedí. Václav to komentuje: „Dobrý den, kdo zdraví, posadí se, kdo nezdraví, nemusí. My už jsme se dneska viděli, tak se nemusíme zdravit." Podobně velkoryse se Václav staví k absenci pomůcek: „Prosím Vás, připravte si sešity do VKO, neboli do výchovy k občanství. Kdo nemá, tak papír." V zásadě se nejedná o pouhou absenci učitelského zásahu, nýbrž o redefinování pole přijatelného žákovského chování. Václav a priori předjímá možnost, že žáci nepovstanou nebo nebudou mít s sebou sešity, a dává najevo, že to od nich nevyžaduje.

Odkázňování se dostavuje rovněž v situacích, kdy žáci odmítnou splnit pokyn učitele, jak dokumentuje ukázka 4.

\section{Ukázka 4:}

V hodině literatury učitelka Hana vyvolává žákyni Nelu.

U: Bude zvonit, když si jenom shrneme, co všechno už jsme se dozvěděli, co všechno už jsme přečetli. Nelo.

Ž Nela: Jenže já jsem furt.

U: Ty furt? Tak někdo jiný.

Ž Dana: (hlásíse)

U: No, Dano?

V ukázce 4 vidíme, že žákyně odpírá učitelce poslušnost, na což učitelka Hana reaguje tím, že se rezistenci žákyně podvoluje. Toto podvolení má charakter uznání práva žáka vyhnout se vyvolání, učitelka nebojuje o prosazení svého požadavku, s lehkostí nabízí možnost odpovědět komukoli jinému ze třídy, kdo se přihlásí. Zároveň vidíme, že tento projev submisivity nevede $\mathrm{k}$ tomu, že by došlo k rozpadu kooperace se žáky. Ihned se hlásí žákyně Dana a ochotně nabízí odpověd', které se žákyně Nela vyhnula. Zde je třeba zdůraznit efekt, který je typický pro všechny techniky snižování dominance učitele popsané v oddílech kapitoly 6.1 Prostor pro žáky a Odkázňování - část moci je přelita od učitele k žákům (učitel ztrácí, žáci získávají), avšak neznamená to, že by žáci nově získanou moc využili k rozbití řádu. $V$ ukázce 4 výuka plynule pokračuje, pro další průběh komunikace tedy nemá neposlušnost žákyně Nely a absence ukáznění ze strany učitelky Hany žádné negativní důsledky.

\section{Záchranná brzda}

Analýza dat ukazuje, že se v repertoáru všech učitelů vyskytují také inverzní postupy vedoucí k omezování prostoru pro žáky a ukázňování. Chápeme je jako druh záchranné brzdy: učitelé směřují k dobrovolnému omezení vlastní 
moci, avšak v momentech, kdy je podle nich potřeba korigovat chování žáků, krátkodobě posílí svoji dominanci.

Nejčastějším typem záchranné brzdy je disciplinační vsuvka, která přichází, pokud je vysoká hladina hluku ve třídě nebo pokud se žáci věnují jiným než zadaným aktivitám. (Př́klad na oba typy z hodin učitele Radka: „Poprosím Katku, začni prosím tě, jestli ti teda spolužáci třeba dovolí mluvit, což by bylo dobrý. Já vím, že je konec školního roku, ale musíme se s tím popasovat." „Oksano, já chápu, že ten telefon je super, ale sbal ho, jo? Děkuju ti. Jo, někam ho schovej, bud' tak hodná. To, že jste na konci hodiny, tak neznamená, že si tady můžete dělat, co chcete.") Tento typ učitelského zásahu dokládá, že tendence k odkázňování není bezbřehá. Liberálnost těchto učitelů spočívá, jak jsme uvedli, v tom, že rozšiřují pole přijatelného žákovského chování. Jakmile ovšem žáci vykročí za tyto rozšířené hranice, učitelé zasáhnou.

To se týká i prostoru, který mají žáci k dispozici. Datový material obsahuje případy, kdy některý ze žáků chce rozvitěji přispět do komunikace, avšak učitel ho umlčí. V jedné z hodin učitelky Hany se pracuje s knihou Kluk v sukních, kterou jeden ze žáků - Mojmír - již četl. Tím pádem velmi pohotově odpovídá na Haniny otázky vztažené k textu. Ta jej nejprve nechává mluvit, ale po určité době mu verbálně i neverbálně začne zamezovat v odpovídání („Ted’ se zeptám, ti z vás, kteří tu knížku nečetli." Otáčí se na Mojmíra, aby nevykřikoval odpověd', a důrazně pokyne hlavou.) Důvodem je snaha zabránit tomu, aby si jediný žák usurpoval př́liš mnoho prostoru, který se tím pádem stane nepř́istupným pro méně pohotové žáky.

Omezování prostoru je obvykle směřováno ke konkrétním žákủm. Paralelně s utlumováním silně participativních žáků jde nátlak na tiché žáky, aby se zapojili více (viz ukázka 5).

\section{Ukázka 5:}

$V$ hodině literatury učitel Jonáš klade otázku do třídy.

Ž Filip: (hlásí se)

U: Někdo jiný.

Ž Lenka: (hlásí se)

U: Někdo jiný.

Ž Jana: (hlásí se a žadoní lítostivým tónem) Proosiím.

U: Prosim vás. Kolik vás tady je? Je nás tady dvacet, vy jste mi to řekli.

Nátlak na žákovskou participaci je charakteristický spíše pro konstelaci přesilovka (viz Šed’ová, 2011). Tam je však směřován k žákům jako celku, nebot' při přesilovce je tř́ída pasivní. Sledovaní učitelé, kteří operují konstelaci 
cirkulace moci, nemusí řešit problém s nízkou odezvou ze třídy, avšak snaží se, aby šance různých žáků zapojit se do komunikace byly pokud možno rovnoměrně rozloženy - to vede k vyvolávání žáků, kteří odpovídat nechtějí. (V kontextu zvýšené míry autonomie a benevolence, kterou jinak tito učitelé žákům dopřávají, jde o protichůdný mechanismus.)

Kromě brzdících mechanismů, které učitelé aktivují ad hoc a po odeznění aktuální potřeby je zase odkládají, používají ještě jeden nástroj, který funguje kontinuálně. Jde o stanovování pravidel, jejich opakované připomínání a socializaci žáků do nich. V konstelaci cirkulace moci jde o nezbytnost, nebot' aktivizační výukové metody, které bývají její součástí, mívají komplikovanou komunikační strukturu. ${ }^{20}$ Platí přitom, že čím složitější je zvolená komunikační struktura, tím podrobněji je třeba definovat pravidla, aby se hodina nezvrhla v chaos.

To lze ilustrovat na vyučovací hodině, v níž učitel Václav poprvé zavádí způsob opakování, při němž si žáci vzájemně kladou otázky z probrané látky. Žák A si zvolí žáka B, tomu položí otázku. Žák B odpoví a vybere si žáka C, jemuž položí další otázku. Ke zviditelnění toho, kdo ke komu hovoří, používá Václav míček, který má hodit vždy dotazující se žák dotazovanému. Celý systém je v hodině opakovaně vysvětlován a žáci jsou opravování, pokud postupují nesprávně. V následujících hodinách se celá struktura postupně habitualizuje a průběh opakování s míčkem se stává hladkým.

\section{Ukázka 6:}

Učitel Václav v hodině občanské výchovy zavádí nový způsob opakování.

U: Dnes budeme opakovat né tak úplně tradičním způsobem, zkusíme dneska takový jakoby malinko jiný způsob. Vždycky, když se opakuje, tak otázky pokládám já (ukazuje na sebe ukazováčkem) a vy na něodpovídáte (ukazováčkem opíše kruh a ukáže na třídu).

Ž Karel: My nebudeme pokládat otázky, že ne?

U: Vy (ukazuje na žáka) budete pokládat otázky. Já hodím balón prvnímu. Ten položí otázku, která souvisí s látkou, kterou jsme dělali minule. Tím totiž já zároveň zjistím, nejen, že ten co odpovídá, ví, ale i ten, co se ptá, vlastně musí vědět, protože musí vědět, co jsme minule dělali. Já vám hodím první balón, ten položí první otázku. Vybere si někoho, komu (ukazuje směrem do trí́dy), komu tu otázku dá, hodí mu balon, chytne ho a takhle pojedeme po řadě. Ten co odpoví, vymýšlí otázku a tak dále a tak dál.

[...]

U: Vždycky oslov někoho, než to hodíš, jo?

$[\ldots]$

20 K běžné komunikační struktuře (tzv. IRF) viz Šed’ová, Švaříček a Šalamounová (2012). 
U: ( $k$ žákovi, který odpovídá a dívá se přitom na učitele) Jemu, jemu odpovídej. (ukazuje směrem na žáka, který položil otázku).

[...]

U: (k žákovi, který položil otázku ve chvíli, kdy vybraný spolužák odpovídá) Na něho se koukej, on to říká.

$[\ldots]$

U: (k žákovi, který položil otázku ve chvíli, kdy vybraný spolužák dokončil odpověd') Můžeš říct, jestli ti to stačí, nebo na to nějak jinak reagovat jako učitel.

[...]

Ž Šárka: (háže míček na spolužačku Míšu)

Ž Míša: Au.

U: Než hodíte míček, oslovte svého spolužáka.

Sledovaní učitelé volí různé způsoby signalizace pravidel. Učitel Jonáš například používá zvedání rukou, kdy zvednutí jedné ruky má jiný význam než zvednutí obou rukou: „Jedna ruka (zvedá ruku) - dáváš argument nebo nějakou otázku, nebo třeba chceš říct jakoby nový téma. Dvě ruce (zvedá obě ruce), když chceš přímo reagovat na člověka, který něco řekl, to znamená protiargument." Vždy však je cílem zajistit totéž - aby v jedné chvíli hovořil jediný člověk, a to dostatečně hlasitě, a ostatní mu naslouchali. Specifická pravidla v hodinách sledovaných učitelů směřují k tomu, aby se žáci se svými promluvami neobraceli pouze na učitele, nýbrž též na své spolužáky (,jemu odpovídej“, „na něho se koukej“). To souvisí s ústupem učitele do pozadí, který byl popsán výše.

Veškeré pozorované jevy, které byly sumarizovány $\mathrm{v}$ této kapitole, svědčí o tom, že rozpouštění dominance je řízená činnost, která vychází ze záměru učitele, nikoli z toho, že by žáci svévolně uchvátili moc. Učitelé jsou schopni míru své dominance „vylad’ovat“ - utlumují ji, protože to odpovídá výukovým formám, které volí, avšak pokud se situace neodvíjí podle jejich představ, centralizují moc znovu do svých rukou.

\subsection{Sjednocování definice situace}

Druhým stavebním kamenem cirkulace moci je shoda na definici situace. V nasbíraných datech se objevily dva vzorce, které vedou k posílení této shody mezi učitelem a žáky. Jde jednak o sociální směnu, kdy učitel poskytuje žákům něco, co je pro ně žádoucí, a žáci jej odměňují dobrým chováním, jednak o synchronizaci emocí. 


\section{Výměnný obchod}

Podstata výměnného obchodu je popsána v sociologických teoriích sociální směny: interakce mezi lidmi má charakter neustálé směny statků a služeb všeho druhu. Harmonie ve vzájemných vztazích se dostavuje, pokud mají všichni zúčastnění pocit, že je pro ně směna výhodná (srov. Keller, 2012). V našem případě je jasné, co chtějí učitelé získat od žáků - aktivní participaci a nízkou míru nekázně. Jako platidlo nabízejí aktivity, které jsou pro žáky zábavné. Z tohoto hlediska lze např́klad používání ICT nahlížet jakou součást výměnného obchodu - učitelka Hana do jedné vyučovací hodiny přinesla tablety pro žáky, kteří potom na internetu vyhledávali informace o spisovatelce Ivě Procházkové. Použití tabletů znamenalo značné zdržení, nebot’ se vyskytly problémy s nastavením sítě a ovládáním tabletů, avšak ve třídě panovalo vzrušené nadšení a žáci byli zjevně zklamaní, když po ukončení dané aktivity dostali pokyn tablety odložit.

Podobně jako práci s tablety žáci ocení jakoukoli audiovizuální prezentaci, obzvláštní oblibě se těší sledování filmů, jak naznačuje ukázka 7.

\section{Ukázka 7:}

$V$ hodině věnované Shakespearovu dramatu Romeo a Julie učitel informuje žáky o tom, že toto dílo bylo zfilmováno.

Ž Simona: A proč se nedíváme na ten film?

U: Protože se učíme pracovat s textem, Simono.

Ž Simona: No ale takhle bysme se učili pracovat s filmem.

ŽŽ: (smích)

U: Ale když neumíš pracovat ani s textem, tak nebudeš umět ani s filmem. Ale budem koukat.

Ž Simona: Jo?

U: Jo.

Ž Dominik: Kdy?

U: Až to doděláme.

V ukázce lze pozorovat, že žáci dávají přednost sledování filmu před čtením textu a že o tom s učitelem explicitně vyjednávají. Učitel je ochoten jim dát, co chtějí („budem se koukat"), ale až poté, co splní zadané úkoly („až to doděláme"). Sledování videa je tak prezentováno jako něco, co žáci dostávají za odměnu. Pokud nepracují dobře, je jim možné tento typ odměny naopak odepř́t.

Součástí výměnného obchodu jsou nepochybně i odkázňovací techniky popsané výše. Jestliže např́íklad učitel Václav nevyžaduje po žácích, aby se 
na začátku hodiny stavěli do pozoru, je to typ směny. Pro žáky je možnost nevstávat jednak určitou úlevou, jednak symbolem spikleneckého spojenectví s učitelem, nebot' jde o odchylku od běžných školních pravidel, jejichž dodržování jiní učitelé vyžadují. Učitel Václav na dané pravidlo může rezignovat proto, že vztahy se žáky považuje za dobré, a nedomnívá se, že mu žáci prokazují málo respektu. $V$ momentě, kdy by se žáci začali chovat drze, udělené privilegium by jim bylo odňato.

V neposlední řadě jsou součástí výměnného obchodu nejrůznější úlevy pro žáky. Učitelé je nechávají rozhodovat o tom, kdy budou zkoušeni, nabízejí jim možnost opravy známek a podobně. Nejdále v tomto směru zašel v průběhu pozorování učitel Radek, který při psaní písemky opustil třídu a žákům tak poskytl možnost odpovědi na zadané otázky opisovat.

\section{Synchronizace emocí}

Výměnný obchod má racionální podstatu, je v něm přítomný kalkul - obě strany vědí, že určitý typ chování jim přinese jisté benefity. Vedle toho však existuje ještě jiná cesta k dosažení shody na definici situace, a to přes sdílení emocí.

V datech lze zaznamenat tři základní strategie, které za tímto účelem učitelé používají: (a) zaujímání vrstevnické pozice; (b) rozdmýchávání nadšení; (c) humor.

Při zaujímání vrstevnické pozice učitel připodobňuje sebe sama k žákům. To vede $\mathrm{k}$ identifikaci žáků s učitelem a k pocitu, že jsou „na stejné vlně“. Učitelé za tímto způsobem používají žákovský jazyk (učitel Václav: „To je těžký jako prase.") nebo předjímají postoje žáků a ukazují, že se s nimi ztotožňují.

\section{Ukázka 8:}

Učitel Radek otevírá hodinu občanské výchovy věnovanou tématu globálních problémů světa.

U: Čím jsme se zabývali minule?

ŽŽ: Globální problémy světa.

U: Dobře. A já jsem vám dal minule otázku a na tu bych rád navázal. Z jakýho důvodu se o tom máme učit, že když já ve vašem věku jsem to považoval za velmi nepř́íjemný téma. Fakt za velmi nepř́ijemný téma, nechtěl jsem o tom slyšet, nechtěl jsem se to učit, považoval jsem to za blbost, v hodině občanky jsme to moc neprožívali tyhle témata. Prostě nebylo to pro mě nic moc.

Ž Elen: To můžeme řešit na každé hodině u každého tématu, co probíráme.

U: Kdo si myslí, že polovina věcí vám nic nepřinese?

(žáci se hlásí) 
Ž Anna: Já si myslím, že víc než polovina.

ŽZ̆: (smích)

U: Já jsem si ve vašem věku, když jsem byl na gymplu, myslel, že je to devadesát procent, a ono to fakt je o tom, že devadesát procent $\mathrm{z}$ těch věcí nikdy nemusíte použít, to vám ř́kám zcela otevřeně.

Učitel Radek v ukázce 8 dosahuje shody na definici situace nikoli tím, že přesvědčí žáky, aby se přiklonili k jeho mínění, nýbrž tím, že se přidá na jejich stranu. Na první pohled ale toto „nadběhnutí“ žákům není patrné, nebot’ celá sekvence není zaranžována jako souhlas učitele se žáky, nýbrž jako souhlas žáků s učitelem, který navíc dávají najevo institucionalizovaným způsobem - hlásí se. Sblížení pozice učitele a žáků má zajímavou konstrukci - sám ze sebe nechává učitel Radek promlouvat své mladší alter ego („když jsem byl na gymplu“) a žáky naopak postaršuje (,já ve vašem věku, když jsem byl na gymplu“ - žáci jsou dosud na základní škole). Tento časový posun zároveň Radkovi umožňuje přeci jen si od žákovské pozice ponechat jistý odstup.

Vrstevnická pozice se dále konstruuje užíváním sdílených popkulturních odkazů. Pokud mají učitel i žáci rádi stejné filmy či zpěváky, vytváří to pro danou chvíli pocit, že jsou členy téže komunity. Popkulturní odkazy s úspěchem užívají učitelé Václav i Radek, jde však o ošemetnou záležitost, nebot' učitelé a žáci přeci jen jsou př́íslušníky různých generací a jejich preference se nemusí protnout. Učitel Jonáš např́íklad pohoří se zmínkou o filmu Žhavé výstřely a zcela mimo se ocitá učitelka Hana, když žákům v hodině pouští píseň o Robinsonovi od Jiřího Korna (ukáže se, že žáci nevědí, kdo Jiří Korn je).

Jestliže pro Hanu není zcela schůdné zaujímat vrstevnickou pozici, kompenzuje to jinou strategií, a tou je rozdmýchávání nadšení. $V$ průběhu hodin (typicky na začátku a na konci) se žáků emfaticky dotazuje, zda je daná kniha baví a žáci vcelku entuziasticky odpovídají.

\section{Ukázka 9:}

Hana avizuje téma knihy, která se bude probírat.

U: Já bych se chtěla zeptat. Myslím si, že klukům se tady to téma bude líbit určitě.

ŽŽ (chlapci): Jo!

U: Chtěla bych se zeptat děvčat (usmívá se).

ŽŽ (dívky) Jó.

Ž Sára: Pohoda.

[...]

Na konci hodiny.

U: Tak. Jak to zakončíme? Pořád vás to ještě baví ta knížka?

ŽŽ: Ano. Jo. 
I ostatní učitelé (včetně Radka, který je jindy s to demonstrovat ve vztahu k učivu značný skepticismus - viz výše) používají tyto techniky, které jsme si pracovně nazvali jako „roztleskávání“. U Jonáše se například žáci, kterým hodina přišla hodnotná nebo je dané téma zajímá, mají hlásit. Ve všech případech jde o vyvolání pozitivní emoční vlny, která projde třídou a má povahu skupinové nákazy; jakmile se začnou někteří žáci hlásit či přizvukovat učiteli, přidají se i další.

Posledním způsobem synchronizování emocí, který jsme zaznamenali ve shromážděném datovém materiálu, je humor. Humor je při sjednocování definice situace velmi efektivní - mezi lidmi, kteří se společně smějí, se vytváŕí pocit vzájemné blízkosti. Smích je synchronizovaná tělesná aktivita a jako taková navozuje synchronizované emoce (viz Šed'ová, 2013).

Humor se vyskytuje $\mathrm{v}$ hodinách všech sledovaných učitelů a je velmi četný. Humor iniciují učitelé, ale jak je v konstelaci cirkulace moci typické, především sami žáci. Učitelé na žákovský humor téměř bez výjimky reagují vstřícně. Obvykle ocení žákovský žert a zasmějí se, ačkoli u toho často hravým způsobem signalizují možnost kázeňské sankce.

\section{Ukázka 10:}

Učitelka Hana se žáky interpretuje povídku Oty Hoffmana Útěk. Řešíse, jak je možné, že se původně neprátelský vztah obou protagonistü, kteř́ se spolu ocitli na útěku, vyvinul v prátelství.

U: A on se bál o to prozrazení, ale i přes to, že si ho vybral proto, aby ho neprozradil, tak se ten vztah potom, ehm, vyvinul v to kamarádství. Tak jak je to možné?

Ž Honza: Černá magie.

U: No černá magie asi to nebude. (zasměje se)

ŽŽ: (smích a šum)

U: Černá magie bude tady za chvilku, až se něco stane. (ukazuje na Honzu)

Hrozba sankce („černá magie bude tady za chvilku“) není míněna vážně a žáci to vědí. Obě strany dokáží humorné výroky dobře interpretovat a zpracovat. Pokud se zdá, že by některý z aktérů nemusel rozpoznat, že je určitý výrok vyřčen v humoru, dodává druhá strana vodítka ke správné intepretaci. Když v hodině učitelky Hany někdo vytvoří mylnou predikci, že kniha Kluk $v$ sukních, je o dívce, která se narodila v chlapeckém těle, žák Antonín to komentuje slovy: „To se stává." Na to se Hana ptá: „To se stává?“ Antonín ihned svůj výrok kontextualizuje: „To byl vtip.“

Mnohdy dochází $\mathrm{k}$ tomu, že se humorné poznámky učitele a žáků řetězí a vznikají škádlivé interakční sekvence, jak dokládá ukázka 11. 


\section{Ukázka 11:}

Učitel Václav chce zapisovat poznámky na tabuli a hledá křídy.

U: Kde máte bílý křídy?

ŽŽ: Nemáme.

Ž František: Nejsou no.

U: Vy jste rasisti, nemáte bílou (jde $k$ tabuli a bere červenou křídu).

Ž František: No my nemáme ani černou.

U: (usměje se) Ani černou. (píše na tabuli)

Ž Štěpán: My jsme tam dali jenom ty červený, aby vám to ladilo ke košili.

U: (otočí se do tř́dy, usměje se) To je od tebe hezký, Štěpáne.

ŽŽ: (smích)

V ukázce 11 (a ostatně též v ukázce 10) je dobře patrné to, co je pro humorné incidenty ve sledovaných hodinách typické: na žert jedné strany reaguje druhá strana rovněž žertem. Nejde tedy o izolované vtipy, které jsou zacíleny na jeden objekt (učitele nebo žáka). $V$ takovém př́padě by totiž humor nevedl $\mathrm{k}$ cirkulaci moci, nýbrž $\mathrm{k}$ posílení mocenské převahy autora vtipu. ${ }^{21}$ V cirkulaci moci se demokraticky stř́ídá autor a objekt vtipu. Smějí se všichni všem (učitel žákům i sám sobě, žáci učiteli, spolužákům a též sami sobě) a tento společný smích vytváří harmonizující pouto, které vede k tvorbě intenzivně prožívaného pocitu skupinové solidarity (viz Šed’ová, 2013). Tímto způsobem humor přispívá k nastolení sdílené definice situace.

\section{Závěr a diskuse}

V tomto příspěvku bylo naším cílem prozkoumat, jak učitelé zacházejí s mocí v kontextu dialogického vyučování. Potvrdili jsme svůj původní předpoklad, že dialogické vyučování je kompatibilní s mocenskou konstelací cirkulace moci. Všichni učitelé, které jsme v průběhu první fáze našeho výzkumného projektu sledovali a jejichž hodiny pro nás reprezentují dialogicky pojatou výuku, operovali v rámci této konstelace. ${ }^{22}$

Dále jsme popsali dílčí elementy, které vedou k ustavení této konstelace. Aby moc ve třídě mohla cirkulovat, musí učitel snížit svoji dominanci, což se podle našich nálezů děje prostřednictvím otevření prostoru pro žáky

21 V konstelaci zobání z ruky se objevují časté vtipy učitele zacílené na žáky, v konstelaci tahanice naopak žáci zesměšňují učitele (viz Šed’ová, 2011, 2013).

22 Je otázkou, zda ustavení mocenských vzorců předchází volbě výukových komunikačních postupů, nebo zda je tomu naopak. Tento spor však nelze s daty, která máme k dispozici, vyřešit. 
a prostřednictvím utlumení kázeňských zásahů učitele. Druhou složkou, která je nezbytná, je dosažení shody na definici situace. K té sledovaní učitelé dospívají prostřednictvím sociální směny a synchronizace emocí.

Otevření prostoru pro žáky je fenomén, který je pro pozorovatele patrně nejviditelnější, a tudíž může sloužit jako základní vodítko pro odlišení cirkulace moci od jiných konstelací. Jde o kategorii, která má velmi zřetelné projevy v oblasti strukturních charakteristik výukové komunikace (typické je např́iklad prodloužení žákovských promluv, kladení otázek žáky apod.), přesto lze říci, že koření v oblasti mocenských vztahů. ${ }^{23}$ Patchen a Smithenry (2014) rozlišují mezi logistickou a epistemickou dimenzí moci, z nichž obě mohou být delegovány na žáky. Logistická dimenze znamená autonomii v rozhodování o pracovním postupu, epistemická znamená autonomii v rozhodování o tom, které vědomosti jsou platné a hodnotné. Oba tyto typy delegování moci, která je v tradičně pojatém vyučování centralizována do rukou učitele, bylo možné $\mathrm{v}$ datovém materiálu zaznamenat. Sledovaní učitelé nechávají alespoň v některých momentech - žáky rozhodovat například o tom, komu bude směřována další otázka (logistická dimenze), ale též o tom, jaké shrnutí si nakonec zapíšou do sešitu (epistemická dimenze). Ruku v ruce s otevíráním prostoru pro žáky jde odkázňování, jehož funkce je patrně spíše symbolická - učitel jeho prostřednictvím vysílá signály, že se nachází ve stádiu dobrovolného utlumení vlastní moci.

Za velmi důležité zjištění považujeme fakt, že ačkoli sledovaní učitelé redukují svoji dominanci, mají v záloze mechanismy záchranné brzdy, které jsou připraveni použít v situaci ohrožení pořádku ve třídě. To dokazuje, že snížení dominance je záměrný a promyšlený krok učitele, který v každé chvíli zvažuje jeho optimální míru.

Elementem, který není tolik nápadný, ale jehož funkce je pro udržení cirkulace moci zcela vitální, je shoda na definici situace. Larkin (1975) uvádí, že učitelé legitimizují svoji moc prostřednictvím sociální směny se žáky. Pokud je učitel s to nabídnout žákům něco, co je pro ně hodnotné (např́íklad svoji náklonnost a nápomocnost), získá jejich důvěru a poslušnost. Pokud takovouto výměnu není schopen či ochoten nabídnout, ve třídě se objeví rezistenční chování a učitel nad žáky musí vykonávat explicitní mocenskou kontrolu prostřednictvím hrozeb a trestů. Tyto Larkinovy (1975) teze vysvětlují, proč

23 To by svědčilo spíše pro hypotézu, že ustavení určité mocenské konstelace predikuje, jakých rysů komunikace mezi učitelem a žáky bude nabývat (viz otázka položená výše). 
mohou být tytéž požadavky od jednoho učitele vnímány jako legitimní (a tudíž jim žáci vyhoví), zatímco od jiného jako nelegitimní (a tudíž jim žáci nevyhoví). Legitimizace moci znamená dosažení shody na definici situace a domnívám se, že teprve, pokud je dosaženo shody mezi učitelem a žákem, může moc cirkulovat. Tomuto předpokladu nasvědčuje pozorování ve výuce učitele Jonáše. Dokud žákům nenabídl úkoly, které pro ně byly zajímavé a do nichž mohli vnést své vlastní životní zkušenosti, projevovali žáci rezistenci, nesouhlas a nudu. Jakmile bylo dosaženo shody na tom, jaká školní práce je pro obě strany přijatelná a hodnotná, začali žáci pracovat se zaujetím a nadšením, Jonáš mohl ustoupit do pozadí a velmi výrazně utlumit mocenskou kontrolu třídy. Dosažení shody tudíž považujeme za primární, teprve následně může učitel decentralizovat moc bez rizika, že se výuka zvrhne v chaos a nekázeň. Právě takovou situaci (rozvrácení řádu v důsledku oslabení moci učitele) totiž dokumentují některé empirické studie citované v teoretické části tohoto příspěvku (Lefstein, 2002; Pace, 2003; Winograd, 2002).

Slabinou tohoto příspěvku je to, že jsme se v analýze koncentrovali na akce učitele. Je totiž třeba věnovat detailní pozornost rovněž tomu, co dělají žáci. Jmenovitě si žádá objasnění jejich role při vytváření společné definice situace - některé typy směn totiž žáci vítají a přistupují na ně, zatímco jiné ignorují. Projev souhlasu či nesouhlasu s požadavky učitele a s jeho výukovým postupem je totiž základní žákovskou zbraní v mocenském vyjednávání. Žáci nemohou diktovat, co se bude ve vyučování dít, avšak učitelé stojí o to, aby žáci projevovali zaujetí či přímo nadšení, a k dosažení tohoto svého cíle jsou ochotni přizpůsobit svůj postup. Ve výsledku tak žákovské reakce na jednání učitele vytváří mantinely pro toto jednání. Podrobné prozkoumání role žáků při ustavování cirkulace moci je za hranicemi možností tohoto příspěvku a představuje výzvu pro další výzkum na tomto poli.

\section{Literatura}

Baker, J. A. (2006). Contributions of teacher-child relationships to positive school adjustment during elementary school. Journal of School Psychology, 44(3), 211-229.

Bloom, D., \& Carter, S. P. (2014). Microethnographic discourse analysis. In P. Albers, T. Holbrook, \& A. S. Flint (Eds.), New methods of literacy research (s. 3-18). New York: Routledge.

Brekelmans, M., Levy, J., \& Rodriguez, R. (1993). A typology of teacher communication style. In T. Wubbels \& J. Levy (Eds.), Do you know what you look like? (s. 46-55). London: The Falmer Press.

Brekelmans, M., Mainhard, T., den Brok, P., \& Wubbels, T. (2011). Teacher control and affiliation: Do students and teachers agree? Journal of Classroom Interaction, 46(1), 17-26. 
Brophy, J. (2010). Classroom management as socializing students into clearly articulated roles. Journal of Classroom Interaction, 45(1), 41-45.

Bruner, J. (1978). The role of dialogue in language acquisition. In A. Sinclair, R. J. Jarvelle, \& W. J. M. Levelt (Eds.), The child's concept of language (s. 241-256). New York: Springer.

Cangelosi, J. S. (1994). Strategie rrízení třídy. Praha: Portál.

Chin, C. (2007). Teacher questioning in science classrooms: Approaches that stimulate productive thinking. Journal of Research in Science Teaching, 44(6), 815-843.

Cornelius, L. L., \& Herrenkohl, L. R. (2004). Power in the classroom: How the classroom environment shapes students' relationships with each other and with concept. Cognition and Instruction, 22(4), 467-498.

De Jong, R. J., van Tarwijk, J., Verloop, N., Veldman, I., \& Wubbels, T. (2012). Teachers' expectations of teacher-student interaction: Complementary and distinctive expectancy patterns. Teaching and Teacher Education, 28(7), 948-956.

Emmer, E. T., \& Evertson, C. M. (2009). Classroom management for middle and high school teachers. Upper Saddle River: Pearson.

Foucault, M. (2000). Dohlížet a trestat. Praha: Dauphin.

French, J. R., \& Raven, B. H. (1959). The bases of social power. In D. Cartwright (Ed.), Studies in social power (s. 150-167). Ann Arbor: Institute for Social Research.

Garrett, T. (2008). Student-centered and teacher-centered classroom management: A case study if three elementary teachers. Journal of Classroom Interaction, 43(1), 34-47.

Gavora, P., Mareš, J., \& den Brok, P. (2003). Adaptácia Dotazníku interakčného štýlu učitela. Pedagogická revue, 55(2), 156-145.

Johnson, B., Whitington, V., \& Oswald, M. (1994). Teachers' view on school discipline: A theoretical framework. Cambridge Journal of Education, 24(2), 261-276.

Keller, J. (2012). Úvod do sociologie. Praha: Sociologické nakladatelství.

Lapointe, J. M., \& Legault, F. (2004). Solving group discipline problems without coercion: An approach based on attribution retraining. Journal of Classroom Interaction, 39(1), 1-10.

Larkin, R. W. (1975). Social exchange in the elementary school classroom: The problem of teacher legitimation of social power. Sociology of Education, 48(4), 400-410.

Lefstein, A. (2002). Thinking power and pedagogy apart - coping with discipline in progresivist school reform. Teachers College Record, 104(8), 1627-1655.

Lefstein, A., \& Snell, J. (2014). Better than best practice. Developing teaching and learning through dialogue. London: Routledge.

Lewis, R. (2001). Classroom discipline and student responsibility: The students' view. Teaching and Teacher Education, 17(3), 307-319.

Lewis, R., Romi, S., Qui, X., \& Katz, Y. J. (2005). Teachers' classroom discipline and student misbehavior in Australia, China and Israel. Teaching and Teacher Education, 21(6), 729-741.

Manke, M. P. (1997). Classroom power relations: Understanding student-teacher interaction. Mahwah: Lawrence Erlbaum Associates.

Mareš, J., \& Gavora, P. (2004). Interpersonální styl učitelů: teorie, diagnostika a výsledky výzkumů. Pedagogika, 54(2), 101-128.

Margutti, P. (2011). Teachers' reproaches and managing discipline in the classroom: When teachers tell students what they do 'wrong'. Linguistic and Education, 22(4), 310-329. 
McCroskey, J., Richmond, V., \& McCroskey, L. (2006). An introduction to communication in the classroom. Boston: Pearsons Education.

McFarland, D. A. (2001). Student resistance: How the formal and informal organisation of classrooms facilitate everyday forms of student defiance. American Journal of Sociology, 107(3), 612-678.

Mortimer, E. F., \& Scott, P. H. (2003). Meaning making in secondary science classrooms. Maidenhead: Open University Press.

O'Connor, E., \& McCartney, K. (2007). Examining teacher-child relationships and achievement as part of an ecological model of development. American Educational Research Journal, 44(2), 340-369.

O'Connor, E., Dearing, E., \& Collins B. A. (2011). Teacher-child relationship and behavior problem trajectories in elementary school. American Educational Research Journal, 48(1), 120-162.

Oliveira, A. W. (2010). Developing elementary teachers' understandings of hedges and personal pronouns in inquiry-based science classroom discourse. Journal of Science Teacher Education, 21(1), 103-126.

Pace, J. (2003). Using ambiguity and entertainment to win compliance in a lower-level US History class. Journal of Curriculum Studies, 35(1), 83-110.

Patchen, T., \& Smithenry, D. W. (2014). Diversifying instruction and shifting authority: A Cultural Historical Activity Theory (CHAT) analysis of classroom participant structures. Journal of Research in Science Teaching, 51(5), 606-634.

Pianta, R. C., \& Stuhlman, M. W. (2004). Teacher-child relationships and children's success in the first years of school. School Psychology Review, 33(3), 444-458

Raven, B. H. (2008). The bases of power and the power/interaction model of interpersonal influence. Analysis of Social Issues and Public Policy, 8(1), 1-22.

Roache, J., \& Lewis, R. (2011). Teachers' view on the impact of classroom management on student responsibility. Australian Journal of Education, 55(2), 132-146.

Reinsvold, L. R., \& Cochran, K. F. (2012). Power dynamics and questioning in elementary science classroom. Journal of Science Teacher Education, 23(7), 745-768.

Richmond, V., \& Roach, D. (1992). Power in the classroom: Seminal studies. In V. Richmond \& J. McCroskey (Eds.), Power in the classroom: Communication, control and concern (s. 47-66). Mahwah: Lawrence Erlbaum Associates.

Šalamounová, Z., Bradová, J., \& Lojdová, K. (2014). Mocenské vztahy mezi začínajícími učiteli a jejich žáky. Pedagogická orientace, 24(3), 375-393.

Šed'ová, K. (2011). Mocenské konstelace ve výukové komunikaci. Studia paedagogica, 16(1), 89-118.

Šed’ová, K. (2013). Humor ve škole. Brno: Masarykova univerzita.

Šed'ová, K., Švaříček, R., \& Šalamounová, Z. (2012). Komunikace ve školní třídě. Praha: Portál.

Šed'ová, K., Švaříček, R., Sedláček, M., \& Šalamounová, Z. (2014). On the way to dialogic teaching: Action research as a means to change classroom discourse. Studia paedagogica, 19(4), 9-35.

Winograd, K. (2002). The negotiative dimension of teaching: Teachers sharing power with the less powerful. Teaching and Teacher Education, 18(3), 343-362.

Woods, P. (1983). Sociology and the school. London: Routledge. 
Wubbels, T., \& Brekelmans, M. (2005). Two decades of research on teacher-student relationships in class. International Journal of Educational Research, 43(1-2), 6-24.

Wubbels, T., Brekelmans, M., den Brok, P., \& van Tartwijk, J. (2006). An interpersonal perspective on classroom management in secondary classrooms in the Netherlands. In C. Evertson \& C. Weinstein (Eds.), Handbook of classroom management: Research, practice and contemporary issues (s. 1161-1191). New York: Lawrence Erlbaum Associates.

Vygotsky, L. S. (1978). Mind in society: The development of higher psychological processes. Cambridge: Harvard University Press.

Zuckerman, J. T. (2007). Classroom management in secondary schools: A study of student teachers' succesful strategies. American Secondary Education, 35(2), 4-16.

\section{Autorka}

doc. Mgr. Klára Šed’ová, Ph.D., Masarykova univerzita, Filozofická fakulta, Ústav pedagogických věd, Arna Nováka 1, 60200 Brno, e-mail: ksedova@phil.muni.cz

\section{Power in dialogic teaching}

Abstract: The aim of this study is to explore the relations of power between the teacher and students in the context of the so-called dialogic teaching, which is a type of teaching that stimulates students' active participation in the teaching communication. Based on data of a research into the implementation of dialogic procedures in humanities at lower secondary schools, the article shows that in dialogic teaching there is circulation of power between the teacher and pupils. This means that the adjustment of mutual relations between teachers and pupils enables functional interchange of power between both parties. Furthermore, the article identifies partial elements of the circulation of power such as the decrease of the dominance of the teacher and the achievement of a consensus about the definition of the situation between the teacher and pupils.

Keywords: power, dialogic teaching, classroom communication 